\title{
THE PROTECTIVE ROLE OF PROPOLIS AGAINST CHLORPYRIFOS INDUCED OXIDATIVE STRESS AND DNA DAMAGE IN THE LIVER OF MALE ALBINO RATS
}

\author{
IBRAHIM, K. A. * and SOAD A. KHWANES \\ Mammalian and Aquatic Toxicology Department, Central Agricultural Pesticides Lab, \\ Giza, Egypt \\ * E-mail address for correspondence: khairy_moneim@yahoo.com
}

(Manuscript received 14 November 2017)

\begin{abstract}
$\mathrm{C}$ hlorpyrifos (CPF) is a conventional chlorinated organophosphate insecticide, it used widely to control a variety of pests in agriculture and animal farm. Acute and chronic exposure to CPF can elicit several adverse effects including oxidative stress and DNA damage. Twenty-eight rats were divided randomly into four groups of seven rats each. The first group was served as control and received distilled water. The second one received aqueous extract of propolis (100 $\mathrm{mg} / \mathrm{kg}$ ). The third group was administered $2.5 \mathrm{mg} / \mathrm{kg}$ of chlorpyrifos $\left(1 / 30 L_{50}\right)$. The fourth group was received propolis two hours before CPF administration. All animals were orally intubated five days/week for four weeks. Results showed that oral administration of CPF led to a significant increase in liver enzymes alanine aminotransferase (ALAT) and aspartate aminotransferase (ASAT) as well as malondialdehyde (MDA) level beside the percentage of DNA damage in liver tissue were increased in contrast with control group. Decrease in serum cholinesterase (ChE) activity as well as liver reduced glutathione (GSH) level, glutathione-S-transferase (GST), glutathione peroxidase (GPx), and glutathione reductase (GR) activities were observed. Co-administration of propolis to CPFtreated group improved all biochemical parameters towards the control value although this treatment couldn't normalize it. The data provide evidence for co-administration of propolis to CPFtreated animals ameliorate the oxidative stress and DNA damage revealed the antioxidant property of propolis.
\end{abstract}

Key words: chlorpyrifos, oxidative stress, DNA damage, propolis, albino rats, liver

\section{INTRODUCTION}

Agricultural Pesticides are used widely in the agricultural production, fruits and vegetables even though they can have adverse health effects on consumers (Keikotlhaile et al., 2010). Organophosphorous (OP) pesticides are the major chemical class of insecticides used in the world today (Bardin et al., 1994). Chlorpyrifos, (O, Odiethyl-o-(3, 5, 6-trichloro-2-pyridinyl) phosphothioate), is a conventional chlorinated organophosphate insecticide, and widely used to control a variety of pests in agriculture and animal farm. It is a well-known acetyl cholinesterase inhibitor which leads to 
accumulation of acetylcholine and results in excessive stimulation of postsynaptic receptors and consequent signs of toxicity (Mehta et al., 2009). Chlorpyrifos has been known to generate oxidative stress by inhibiting enzymatic antioxidant defense (Verma \& Srivastava, 2003), and also induces DNA damage (Mehta et al., 2009). Liver is the main site for all metabolic processes and detoxification of toxic compounds. Thus, it is likely to be affected also by CPF (Joshi et al., 2007).

Propolis (bee glue) is the generic name for the resinous substances collected by honey bees from various plant sources. Propolis contains more than 300 components, including phenolic aldehyde, quinines, coumarins, steroids, amino acids and inorganic compounds (Kanbur et al., 2009). It has gained popularity and used extensively in healthy drinks and foods to improve well-being and prevent diseases, also it possesses several biological and antioxidant properties (Marquele et al., 2005). Thus, the present study was conducted to evaluate the efficacy of propolis aqueous extract against the oxidative stress and DNA damage in liver tissue resulting from chlorpyrifos administration.

\section{MATERIALS AND METHODS}

\section{Chemicals used}

Chlorpyrifos "CPF" (48\% EC) was obtained from Department of Pesticides Analysis, Central Agricultural Pesticides Lab., Dokki, Egypt. 2-thiobarbituric acid (TBA), 1-chloro 2,4-dinitrobenzoic acid (CDNB), reduced glutathione, nicotinamide adenine dinucleotide phosphate (NADPH), 5,5'-dithiobis-2-nitrobenzoic acid (DTNB), pyrogallol, trichloro acetic acid, sodium azied and Tris-HCl were purchased from Sigma-Aldrich. All other chemicals and solvents analytical grade purchased from Merck.

\section{Experimental protocol}

\section{Animals}

A total of 48 adult male albino rats (Rattus norvegicus) weighting $180 \pm 10$ grams and 12-14 weeks age were obtained from the breeding colony of the Mammalian and Aquatic Toxicology Department, Central Agricultural Pesticides Lab, Giza, Egypt. The animals were randomly housed in well ventilated wire-plastic cages and wood shaving as bedding materials at a temperature of $25 \pm 2^{\circ} \mathrm{C}$ and humidity of $55 \pm 5 \%$ and normal light/dark cycle. The animals were maintained on the standard laboratory feed and water ad libitum.

\section{Acute oral toxicity study}

The acute oral median lethal dose $\left(\mathrm{LD}_{50}\right)$ was undertaken according to the Environmental Protection Agency (EPA) guideline (EPA, 1996). A twenty rats were divided into four groups (each five animals) and the mortality was recorded through the 
first 6 hours up to 14 days post intubation. The value of $L D_{50}$ was calculated using special tables given by Weil (1952).

\section{Sub-acute study}

Twenty eight animals were segregated into 4 groups of 7 rats each. The first group was served as control and received distilled water. The second one was received aqueous extract of propolis $100 \mathrm{mg} / \mathrm{Kg}$ (Faried et al., 2015). The third group was administered $2.5 \mathrm{mg} / \mathrm{kg}$ of chlorpyrifos $\left(1 / 30 \mathrm{LD}_{50}\right)$. The fourth group was received propolis $2 \mathrm{hr}$ before chlorpyrifos administration. All animals were orally intubated five days/week for four weeks.

\section{Sample collection}

At the end of the experiment, the animals were starved overnight and the blood samples were collected from retero-orbital venous plexus under diethyl ether anaesthesia. Finally rats were sacrificed, liver of each animal were quickly removed and washed in normal saline solution. The obtained sera and the liver were stored at $-20^{\circ} \mathrm{C}$ until used for biochemical assays.

\section{Biochemical estimations}

Serum ALAT and ASAT activities were estimated according to the method of Young (1990) using the commercial kits of MDSS GmbH, (Germany) according to manufacture instruction. Plasma ChE activity was determined according to the method of Ellman et al. (1961) by using acetyl thiocholin iodide as substrate and activity expressed as $\mu \mathrm{m} / \mathrm{min} / \mathrm{ml}$.

\section{Lipid peroxidation and antioxidant enzymes Tissue preparation}

The liver was homogenized individually in $1.17 \% \mathrm{KCl}$ on an ice bath using Teflon homogenizer. The whole homogenate was used to measure MDA and GSH. The homogenate was centrifuged at 10,000 $\mathrm{xg}$ for $20 \mathrm{~min}$. and the supernatant was used for measurements of GPx, GST, GR activities and protein content.

\section{Lipid peroxidation}

Content of MDA in liver tissue homogenate, indicator for lipid peroxidation, was assayed in the form of TBA-reactive species (TBARS) according to the method of Wills (1966), and the level of MDA was expressed as $\mathrm{nmol} / \mathrm{g}$ tissue.

\section{Estimation of GSH concentration}

Reduced glutathione was determined by the method of Ellman (1959). The liver homogenate $(0.5 \mathrm{ml})$ was precipitated with $2 \mathrm{ml}$ of $5 \%$ TCA, then centrifuged at 3200 $\mathrm{xg}$ for $20 \mathrm{~min}$. one $\mathrm{ml}$ of supernatant was added to $0.5 \mathrm{ml}$ of Ellman's reagent and 3.0 
$\mathrm{ml}$ of phosphate buffer (0.2M PH 8.0). The absorbance was read at $412 \mathrm{~nm}$ and the content of GSH was expressed as $\mathrm{mg} / \mathrm{g}$ tissue.

\section{Determination of GPx activity}

GPx activity was carried out according to the method Necheles et al. (1969) which based on the measurement of residual reduced glutathione remaining by Ellman's reagent (Ellman, 1959) in the presence of cumene hydroperoxide as a secondary substrate. The specific activity of enzyme expressed as $\mu \mathrm{M} / \mathrm{min} / \mathrm{mg}$ protein. The protein content in tissue fraction was done based on the method of Bradford (1976).

\section{Determination of GST activity}

The GST enzyme activity was assay by the method of Habig et al. (1974). The reaction medium contains $0.95 \mathrm{ml}$ of phosphate buffer $\mathrm{PH} 6.5(0.1 \mathrm{M}), 20 \mu \mathrm{l}$ of $1.0 \mathrm{mM}$ $\mathrm{GSH}, 20 \mu \mathrm{l}$ homogenate and $10 \mu \mathrm{l}$ of $1.0 \mathrm{mM}$ CDNB. The absorbance was measured at $340 \mathrm{~nm}$ and the specific activity was expressed in $\mu \mathrm{m} / \mathrm{min} / \mathrm{mg}$ protein.

\section{Determination of GR activity}

The activity of GR was determined using the method of Coldberg \& Spooner (1983). The enzyme activity was measured spectrophotometrically by following decrease in absorbance of NADPH at $340 \mathrm{~nm}$ in a sodium phosphate buffer (50 mM, pH 7.6) containing $1 \mathrm{mM}$ EDTA, $0.17 \mathrm{mM} \mathrm{NADPH}$, and $3.3 \mathrm{mM}$ oxidized glutathione. The specific activity was expressed as $\mu \mathrm{m} / \mathrm{min} / \mathrm{mg}$ protein.

\section{Single Cell Gel Electrophoresis}

The comet assay was performed under alkaline conditions by procedure of Singh et al. (1988). A freshly prepared suspension of liver was mixed with $0.7 \%$ low melting point agarose and casted to precoated slides with $1 \%$ normal melting agarose. The cells were then lysed for 1 hour at $4^{\circ} \mathrm{C}$ in a buffer consisting of $2.5 \mathrm{M} \mathrm{NaCl}, 100 \mathrm{mM}$ EDTA, $1 \%$ Triton X-100, $10 \mathrm{mM}$ Tris, $\mathrm{pH} 10$. The slides were then placed in the electrophoretic buffer consisting of $300 \mathrm{mM} \mathrm{NaOH}, 1 \mathrm{mM}$ EDTA, pH > 13 for $40 \mathrm{~min}$. Electrophoresis was conducted for $30 \mathrm{~min}$ at electric field strength $0.56 \mathrm{~V} / \mathrm{cm}(300 \mathrm{~mA})$. The slides were then neutralized with $0.4 \mathrm{M}$ Tris, $\mathrm{pH} 7.5$ and stained with eithidum bromide before examination under a fluorescence microscope (Lx 400, Labomed, USA) with $590 \mathrm{~nm}$ as a barrier filter. Analysis was performed on coded slides by one reader to avoid variability by komet 5 image analysis software (Liverpool, UK) linked to a CCD camera.

\section{RESULTS AND DISCUSSION}

As seen in (Table 1), no significant differences were observed in the serum ALAT and ASAT activities in the group that was administered propolis alone. On the other hand, a significant increase in ALAT and ASAT activities in CPF group and propolis administered group in association with chlorpyrifos when compared with control group. 
The treatment with prolpolis alone did not induce any significant alteration in serum ChE activity compared with control group. Treatment rats with CPF alone and propolis administered group in combination with chlorpyrifos reduced ChE activity compared with control group.

The administered propolis group did not display any significant difference in liver MDA level in comparison with the control group. On the other hand, a significant elevation in the liver MDA level was observed in both groups that administered CPF alone and that was administered propolis in association with CPF.

The present study revealed that rats treated with propolis extract alone resulted in a significant increase in reduced glutathione level, GPx and GR activity, and no significant change in GST activity was observed. However, chlorpyrifos treated group produced a significant decrease in GSH level, GPx, GST and GR activities. Coadministration of propolis extract to chlorpyrifos treated group improved the level of GSH as such as GPx, GST and GR activities, but the data still below the normal values as compared to the control group (table 1 ).

The CPF-treated group revealed a significant increase in tail DNA, damage index, tail length and tail moment, and the less effect was observed in co-administration propolis group compared with control one (table 2 and figure 1 ).

Table 1. The protective role of propolis on chlorpyrifos induced alteration in liver enzymes, cholinesterase and antioxidant enzymes.

\begin{tabular}{|c|c|c|c|c|c|c|c|c|}
\hline Groups & $\begin{array}{c}\text { ALAT } \\
\text { U/L }\end{array}$ & $\begin{array}{c}\text { ASAT } \\
\text { U/L }\end{array}$ & $\begin{array}{c}\text { CHE } \\
\mu \mathrm{m} / \mathrm{min} / \\
\mathrm{ml}\end{array}$ & $\begin{array}{c}\text { MDA } \\
\text { nmol/ } \\
\text { g tissue }\end{array}$ & $\begin{array}{c}\text { GSH } \\
\mathrm{mg} / \\
\mathrm{g} \text { tissue }\end{array}$ & $\begin{array}{c}\text { GPX } \\
\mu \mathrm{m} / \mathrm{min} / \\
\mathrm{mg} \\
\text { protein }\end{array}$ & $\begin{array}{c}\text { GST } \\
\mu \mathrm{m} / \mathrm{min} / \\
\mathrm{mg} \\
\text { protein }\end{array}$ & $\begin{array}{c}\mathrm{GR} \\
\mu \mathrm{m} / \mathrm{min} \\
\mathrm{mg} \\
\text { protein }\end{array}$ \\
\hline \multirow[t]{3}{*}{ Control } & 34.85 & 77.85 & 209.92 & 340.64 & 25.94 & 348.88 & 204.96 & 178.02 \\
\hline & \pm & \pm & \pm & \pm & \pm & \pm & \pm & \pm \\
\hline & 0.40 & 1.56 & 8.50 & 10.98 & 0.33 & 4.59 & 5.87 & 1.49 \\
\hline \multirow[t]{3}{*}{ Propolis } & 35.00 & 79.28 & 195.46 & 338.63 & 29.60 & 363.38 & 209.19 & 181.58 \\
\hline & \pm & \pm & \pm & \pm & \pm & \pm & \pm & \pm \\
\hline & $0.30^{c, d}$ & $0.42^{c, d}$ & $9.66^{c}$ & $13.40^{c, d}$ & $0.34^{\mathrm{a}, \mathrm{c}, \mathrm{d}}$ & $1.79^{a, c, d}$ & $5.06^{\mathrm{cd}}$ & $0.74^{\mathrm{a}, \mathrm{c}, \mathrm{d}}$ \\
\hline \multirow[t]{3}{*}{ chlorpyrifos } & 44.42 & 99.14 & 145.42 & 756.38 & 18.75 & 279.22 & 136.90 & 139.98 \\
\hline & \pm & \pm & \pm & \pm & \pm & \pm & \pm & \pm \\
\hline & $0.57^{\mathrm{a}, \mathrm{b}, \mathrm{d}}$ & $0.85^{\mathrm{a}, \mathrm{b}, \mathrm{d}}$ & $7.13^{\mathrm{a}, \mathrm{b}, \mathrm{d}}$ & $30.26^{\mathrm{a}, \mathrm{b}, \mathrm{d}}$ & $0.48^{\mathrm{a}, \mathrm{b}, \mathrm{d}}$ & $3.67^{a, b, d}$ & $3.55^{a, b, d}$ & $0.81^{1, b, d}$ \\
\hline \multirow[t]{3}{*}{ Propolis+chlorpyrifos } & 38.28 & 90.42 & 183.14 & 522.87 & 21.40 & 332.08 & 166.09 & 161.25 \\
\hline & \pm & \pm & \pm & \pm & \pm & \pm & \pm & \pm \\
\hline & $0.42^{\mathrm{a}, \mathrm{b}, \mathrm{c}}$ & $0.64^{\mathrm{a}, \mathrm{b}, \mathrm{c}}$ & $6.84^{a, c}$ & $16.39^{\mathrm{a}, \mathrm{b}, \mathrm{c}}$ & $0.46^{a, b, c}$ & $3.18^{a, b, c}$ & $2.98^{\mathrm{a}, \mathrm{b}, \mathrm{c}}$ & $0.94^{a, b, c}$ \\
\hline
\end{tabular}

The data presented as mean $\pm S E,(n=7)$; (a) significantly different at $p<0.05$ in compared to the control group; (b) compared to propolis; (c) compared to chlorpyrifos and (d) compared to propolis plus chlorpyrifos. 
Table 2. The protective role of propolis on chlorpyrifos induced alteration in DNA.

\begin{tabular}{ccccc} 
Groups & Tail DNA & Damage Index & Tail Length & Tail Moment \\
\hline \multirow{2}{*}{ Control } & 3.00 & 3.80 & 1.84 & 5.81 \\
& \pm 0.70 & \pm 0.83 & \pm 0.13 & \pm 0.69 \\
\hline \multirow{2}{*}{ Propolis } & 2.80 & 3.4 & 1.74 & 5.01 \\
& $\pm 0.83^{\mathrm{c}, \mathrm{d}}$ & $\pm 1.14^{\mathrm{c}, \mathrm{d}}$ & $\pm 0.07^{\mathrm{c}, \mathrm{d}}$ & $\pm 0.18^{\mathrm{c}, \mathrm{d}}$ \\
\hline \multirow{2}{*}{ chlorpyrifos } & 33.80 & 72.8 & 7.45 & 23.45 \\
& $\pm 3.27^{\mathrm{a}, \mathrm{b}, \mathrm{d}}$ & $\pm 8.31^{\mathrm{a}, \mathrm{b}, \mathrm{d}}$ & $\pm 0.64^{\mathrm{a}, \mathrm{b}, \mathrm{d}}$ & $\pm 1.61^{\mathrm{a}, \mathrm{b}, \mathrm{d}}$ \\
\hline \multirow{2}{*}{ Propolis+chlorpyrifos } & 18.40 & 30.80 & 4.05 & 13.52 \\
& $\pm 2.07^{\mathrm{a}, \mathrm{b}, \mathrm{c}}$ & $\pm 5.31^{\mathrm{a}, \mathrm{b}, \mathrm{c}}$ & $\pm 0.18^{\mathrm{a}, \mathrm{b}, \mathrm{c}}$ & $\pm 0.51^{\mathrm{a}, \mathrm{b}, \mathrm{c}}$ \\
\hline
\end{tabular}

The data presented as mean $\pm S E,(n=7)$; (a) significantly different at $p<0.05$ in compared to the control group; (b) compared to propolis; (c) compared to chlorpyrifos and (d) compared to propolis plus chlorpyrifos.
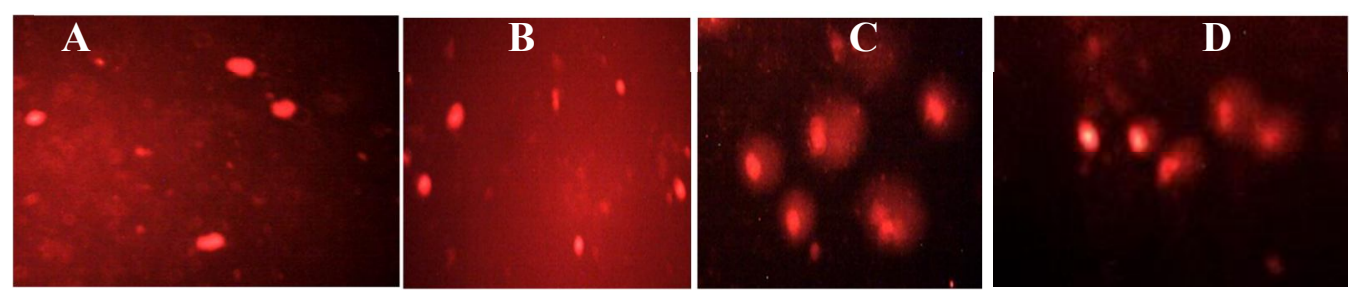

Fig. 1. Microscopic scoring of DNA damage in liver tissue. (A) control group, (B) propolis group, (C) chlorpyrifos group, and (D) propolis plus chlorpyrifos group.

The liver plays an important role in the detoxification of xenobiotics, the disturbance of liver homeostasis under oxidative imbalance is sufficient to alter the normal physiological functioning of any organism (Joshi et al., 2007). The organophosphate insecticides induced an increase in ALAT and ASAT activities in both groups that administered CPF only and in association with propolis and this fact is a conventional indicator of liver injury. When the liver cell membrane is damaged, varieties of enzymes normally located on the cytosol are released into the blood stream, elevation in ALAT and ASAT indicates the utilization of amino acids for the oxidation or for glucogenesis and is used to determine liver damage (Rao, 2006).

The results revealed that either CPF alone or combination with propolis induced a significant inhibition in the activity of ChE compared to the control rats. CPF after ingestion, is subjected to microsomal oxidation in the liver, resulting in the formation of CPF-oxone, which is a potent inhibitor of AChE in the peripheral tissues and CNS (Mehta et al., 2009).

Pesticides are known to produce oxidative stress, results of the present study showed that exposure to CPF caused increase in lipid peroxidation, which has been used 
as measure of xenobiotics-induced oxidative stress, which was originally defined as the disequilibrium between pro-oxidants and antioxidants in biological system (Kelly et al., 1998). Which leads to damage of cellular macromolecules or cell death by free radicals. The increase in MDA levels may be due to a possible increase in free radicals caused by CPF (Gultekin et al., 2001). Rats that were administered propolis in association with CPF in compared to the CPF alone, showed decrease in liver MDA level, may be due to scavenging of free radicals that cause lipid peroxidation or may be due to inhibition of xanthine oxidase which is known to cause free radical to be generated by propolis (Harris et al., 2000).

GSH acts as reducing agent and a vital substance in detoxification, also provides antioxidant protection in the aqueous phase of cellular system (Rana et al., 2002) GSH also acts as substrate and co-substrate in many essential enzymatic reactions such as GPx and GST.

Chlorpyrifos treated group produced a significant decrease in GSH level, GST, GPx and GR activities. The data are consistent with Gupta et al. (2010) who found that chlorpyrifos lead to oxidative damage to various tissues or cells. CPF is known to cause depletion of reduced glutathione and decrease in the ratio of GSH/GSSG in rat tissues which is maintained intracellularly through the action of GR and NADPH dependent reaction, and causes inhibition of antioxidant enzyme activities in liver rats (Verma \& Srivastava, 2003).

Depletion of cellular GSH below a critical level prevents the conjugation of xenobiotics to GSH and enables them to freely combine covalently with DNA, RNA or cell proteins resulting in cellular damage (Meister \& Anderson, 1993). Reduction of GSH by xenobiotics below a certain level allow the enhancement of lipid peroxidation and induction of ROS, which could also cause formation of DNA single strand breaks (Banu et al., 2001), as it clear in the present study in which CPF causes DNA damage in liver tissues, as evidenced by increase in DNA migration which was detected by comet assay.

Animals that were administered propolis in association with chlorpyrifos were alleviated the negative effects of CPF-treated group on GSH level, GPx, GST and GR activities. This may be due to the phenolic compounds existing in propolis extract which responsible for the antioxidant activity (Kanbur et al., 2009).

\section{CONCLUSION}

The present study clearly shows that CPF exposure generates oxidative stress in rat hepatic tissue which is an additional toxic effect other than DNA damage. Which was also corroborated by the protection provided by aqueous extract of propolis. 


\section{REFERENCES}

1. Banu, B. S.; K. Danadevi; M. F. Rahman; Y. R. Ahuja and J. Kaiser. 2001. Genotoxic effect of monocrotophos to sentinel species using comet assay. Food Chem Toxicol 39:361-366.

2. Bardin, P. G.; S. Van Eeden; J. A. Moolman; A. P. Foden and J. R. Joubert. 1994. Organophosphate and carbamate poisoning. Arcg Intern Med 154: 1433-1441.

3. Bradford, M. M. 1976. A rapid and sensitive method for the quantitation of microgram quantities of protein utilizing the principle of protein-dye binding. Analytical Biochemistry. 72: 248-254.

4. Coldberg, D. M. and R. J. Spooner. 1983. In the methods of enzymatic analysis (Bergmeyen, H. V. Ed.) 3rd Ed. Vol. 3, pp258 - 265, Verlag Chemie, Deerfield Beach, F1.

5. Ellman, G. L. 1959. Tissue sulfhydryl groups. Archives of Biochemistry and Biophysics. 82: 70-77.

6. Ellman, G. L.; K. D. Courtney; V. Andres and R. M. Feather-Stone. 1961. A new and rapid colorimetric determination of acetylcholinesterase activity. Biochem. Pharmacol. 7:88-95.

7. EPA. 1996. Triadimefon (Bayleton) Pesticide Tolerance. Federal Register, pp: 63721-63726.

8. Faried, A. E.; M. E. Wafaa; M. E. El-Sayed and G. E. Shady. 2015. Influence of propolis on oxidative stress, inflammation and apoptosis in streptozotocin induced diabetic rats. Intern. J. Advan. Res. 3(7):831-845.

9. Gultekin, F.; N. Delibas; S. Yasar and I. Kilinc. 2001. In vivo changes in antioxidant systems and protective role of melatonin and a combination of vitamin $\mathrm{C}$ and vitamin $\mathrm{E}$ on oxidative damage in erythrocytes induced by chlorpyrifos-ethyl in rats. Arch Toxicol 75:88-96.

10. Gupta, S. C.; M. Mishra; A. Sharma, T. G. R. D. Balaji; R.Kumar, and R. K. Mishra. 2010. Chlorpyrifos induces apoptosis and DNA damage in drosophila through generation of reactive oxygen species. Ecotox. Environ. Safe. 73: 1415-1423.

11. Habig, W. H.; M. J. Pabst and W. B. Jakoby. 1974. Glutathione-S-Transferases. The first enzymatic step in mercapturic acid formation. J. Biol. Chem. 249:71307139.

12. Harris, S. R.; N. J. Panaro and U. P. Thorgeirsson. 2000. Oxidative stress contributes to the anti-proliferative effects of flavone acetic acid on endothelial cells. Anticancer Res. 20: 2249-2254.

13. Joshi, S. C.; R. Mathur and N. Gulati. 2007. Testicular toxicity of chlorpyrifos (an organophosphate pesticide) in albino rat, Toxicol. Indus. Health 23: 439-444.

14. Kanbur, M.; G. Eraslana and S. Silicib. 2009. Antioxidant effect of propolis against exposur etopropetamphos in rats. Ecotoxicol. Environ. Safety, 72:909-915. 
15. Keikothaile, B.M.; P. Spanoghe and, W. Steurbaut. 2010. Effects of food processing on pesticide residues in fruits and vegetables: a meta-analysis approach. Food Chem. Toxicol. 48, 1-6.

16. Kelly, S. A.; K. M. Harvilla; T. C. Brady; K. H. Abrano and E. D. Leveir. 1998. Oxidative stress in toxicology: established mammalian and emerging piscine model systems. Env HIth Perspect 106: 375-384.

17. Marquele, F. D.; V. M. Di Mambro; S. R. Georgetti; R. Casagrande; Y. M. L. Valim and M. J. V. Fonseca. 2005. Assessment of the antioxidant activities of Brazilian extracts of propolis alone and in topical pharmaceutical formulations, J. Pharmacol. Biomed. Anal. 39:455-462.

18. Mehta, A.; R. S. Verma and N. Srivastava. 2009. Chlorpyrifos-induced alterations in the levels of hydrogen peroxide nitrate and nitrite in rat brain and liver. Pest. Biochem. Phys., 94: 55-59.

19. Meister, A. and M. E. Anderson. 1993. Glutathione. Ann Rev Biochem 32: 711-760.

20. Necheles, T. F.; N. Maldonado; A. Barquet-Chediak and D. M. Allen (1969): Brief report: Hemozygous erythrocyte glutathione-peroxidase deficiency: clinical and biochemical studies. Blood. 33: 164-169.

21. Rana, S. V. S.; T. Allen and R. Singh. 2002. inevitable glutathione, then and now Ind J Exp Biol 40: 706-716

22. Rao, J. V. 2006. Biochemical alterations in euryhaline fish, Oreochromis mossambicus exposed to sub-lethal concentrations of an organophosphorous insecticide, monocrotophos. Chemosphere 65: 1814-1820.

23. Singh, N. P.; M. T. McCoy; R. R. Tice and E. L. Schneider. 1988. A simple technique for quantification of low levels of DNA damage in individual cells. Exp. Cell Res. 175: 184-191.

24. Verma, R. S. and N. Srivastava. 2003. Effect of chlorpyrifos on thiobarbituric acid reactive substances, scavenging enzymes and glutathione in rat tissues. Indian J Biochem Biophys 40: 423-428.

25. Weil, C. S. 1952. Tables for convenient calculation of medium effective dose ( $L_{50}$ or $\left.\mathrm{EC}_{50}\right)$ and instruction in their use. Biometrics. 8: 249-263.

26. Wills, E. D. 1966. Mechanisms of Lipid Peroxide Formation in Animal Tissues. Biochem. J. 99: 667-676.

27. Young, D. S. 1990. effects of drugs on clinical laboratory tests. 3rd edition, 3: 612. 


\section{الاور الوقائى لصمغ النحل ضد التأثير التأكسدى والخلل الناجم فى الحامض النووى من مبيد الكلوربيرفوس فى كبد ذكور الجرزان البيضاء}

\section{خيرى عبدالمنعم ابر اهيم و سعاد أحمد ابر اهيم}

$$
\text { قسم سمبة المبيدات للثيات والأحياء المائية- المعدل المركزي للمبيدات- مركز البحوث الزراعية - الدقي }
$$

يعتبر مبيد الكلوربيريفوس من المركبات الفوسفورية العضوية التقلدية وعلى الرغم من انه يستخدم على نطاق و اسع ضد مجموعة متتوعة من الآفات الزر اعية الا ان التعرض الحاد و المزمن من لئن

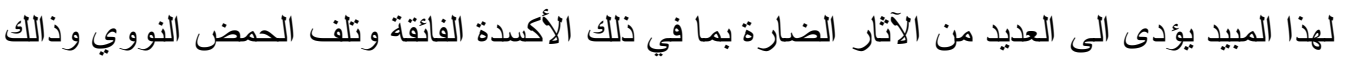

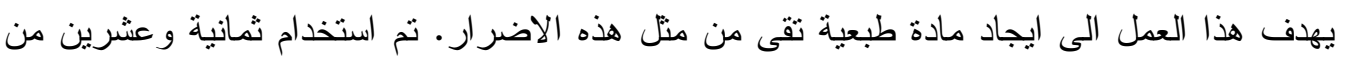

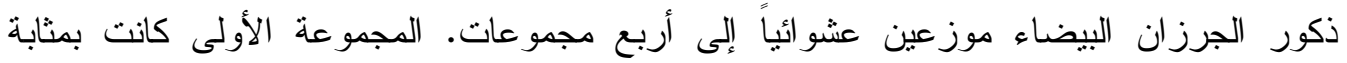

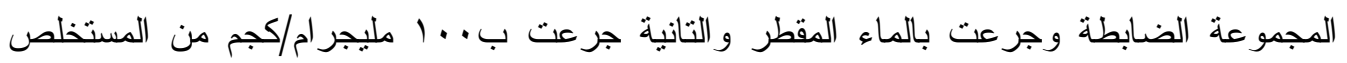

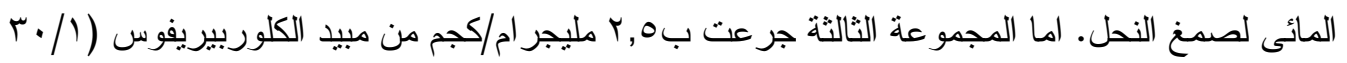
من الجرعة نصف المميتة) والر ابعة فقد جرعت بنفس الجرعة من المستخلص المائى لصمغ النحل

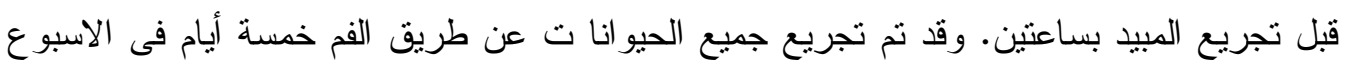

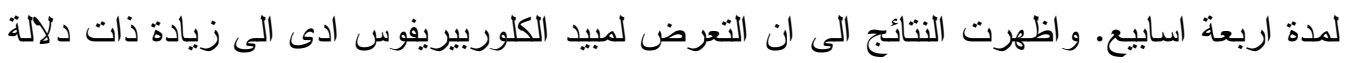

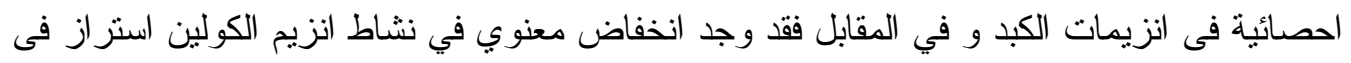

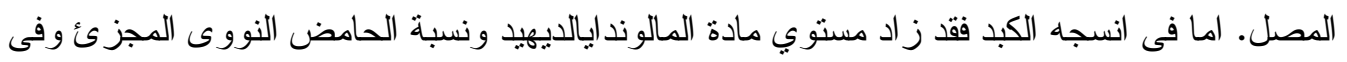
المقابل فقد انخفض مستوى مادة الجلوناثيون وكذاللك النشاط الانزيمى لكلا من الجلوتاثيون-استر انسفيريز و انزيم الجلوتاثيون ريدكتيز عند المقارنة بالمجموعة الضابطة. اوضحت النتاج ايضا ان

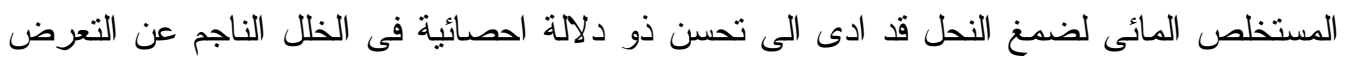
لمبيد الكلوربيريفوس لذاللك من المكن ان يستخدم كمادة وقائية لجميع المشتغلين في مجال المبيدات.

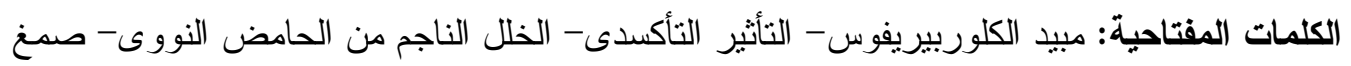

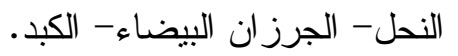

